Supplement of Biogeosciences Discuss., 12, 13375-13397, 2015

http://www.biogeosciences-discuss.net/12/13375/2015/

doi:10.5194/bgd-12-13375-2015-supplement

(C) Author(s) 2015. CC Attribution 3.0 License.

(c) (i)

Supplement of

\title{
Hydroxy fatty acids in fresh snow samples from northern Japan: long- range atmospheric transport of Gram-negative bacteria by Asian winter monsoon
}

\section{P. Tyagi et al.}

Correspondence to: K. Kawamura (kawamura@lowtem.hokudai.ac.jp)

The copyright of individual parts of the supplement might differ from the CC-BY 3.0 licence. 
Table S1: Two-tailed t-test to ascertain the statistical significance of ratio of relative abundances of even to odd carbon number hydroxy FAs in snow samples collected from the Sapporo between winter-2010 and 2011.

\begin{tabular}{cccc}
\hline even/odd & $\mathbf{2 0 1 0}$ & $\mathbf{2 0 1 1}$ & t-score, df, P-value \\
\hline$\alpha$-hydroxy FAs & $2.4 \pm 0.3$ & $2.2 \pm 0.3$ & $1.4,7,>0.05$ \\
$\beta$-hydroxy FAs & $2.9 \pm 0.8$ & $1.8 \pm 0.6$ & $2.5,9,<0.05$ \\
$\omega$-hydroxy FAs & $15.8 \pm 4.5$ & $3.2 \pm 1.8$ & $5.8,7,<0.05$ \\
\hline
\end{tabular}

1000m AGL

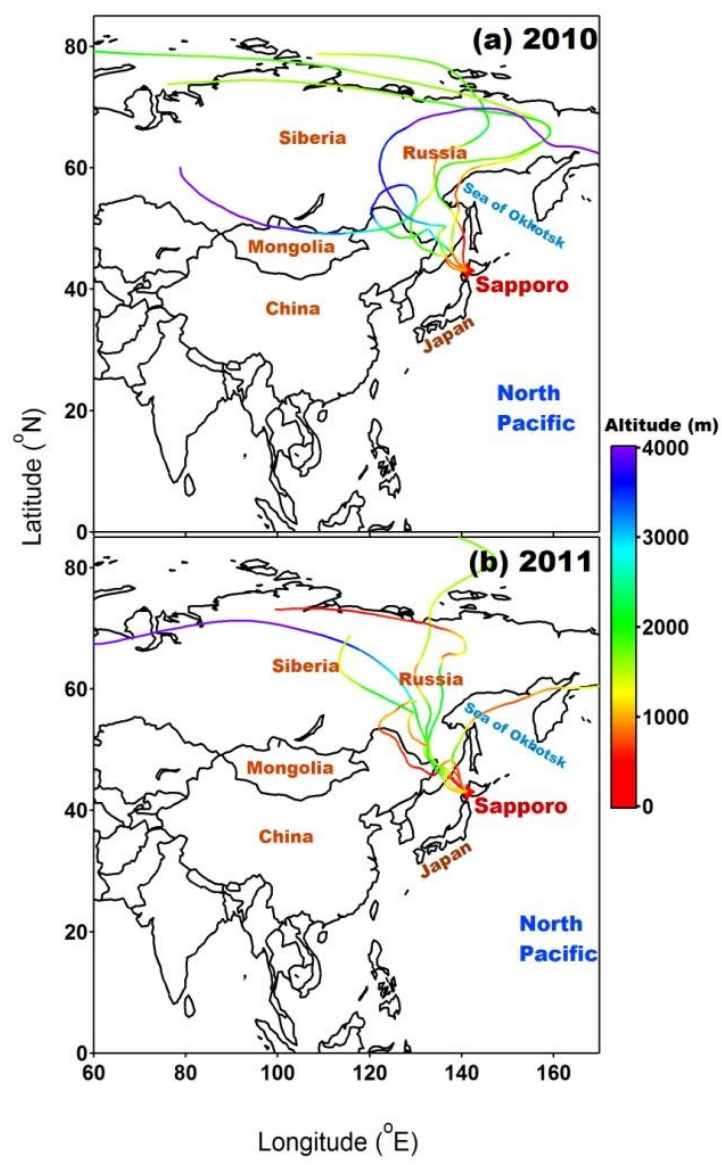

$1500 \mathrm{~m}$ AGL

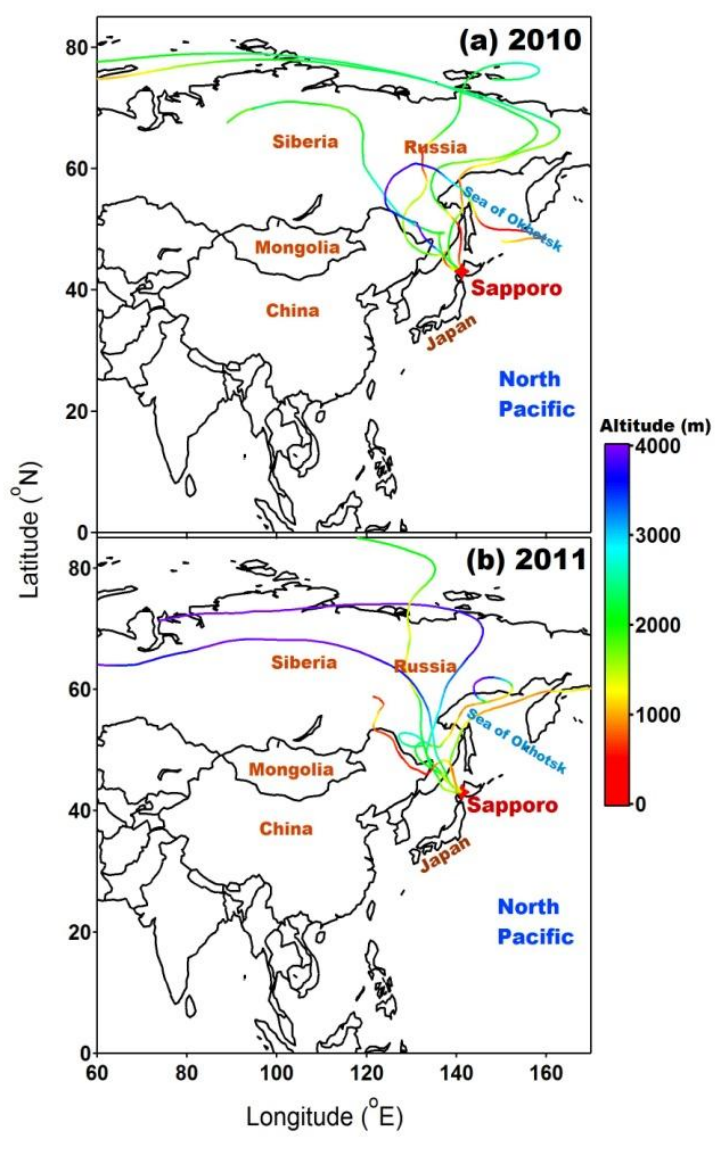

Figure S1. Air mass back trajectory cluster at an arrival heights of 1000 and 1500m AGL (above ground level) for the sampling days in (a) winter 2010 and (b) winter 2011. 